\title{
Participatory education and challenges in a fragmented world A holistic approach to urban planning for a sustainable future
}

\begin{tabular}{|c|c|}
\hline \multicolumn{2}{|r|}{$\begin{array}{l}\text { Barbara Dickens }{ }^{*} \\
\text { Flinders University Masters Graduate }\end{array}$} \\
\hline Article history & In our 'complex, fragmented urban world' (Stoker,2000 ) 'global \\
\hline $\begin{array}{l}\text { Received: } \\
01.03 .2015\end{array}$ & $\begin{array}{l}\text { problems are generated at the local scale and should be solved there } \\
\text { too' (Condon,2008). Yet, neither governments nor citizens take }\end{array}$ \\
\hline $\begin{array}{l}\text { Received in revised form: } \\
20.06 .2015\end{array}$ & $\begin{array}{l}\text { responsibility for the collective problems, while political systems } \\
\text { focus on short-term rather than long term benefits. McIntyre-Mills }\end{array}$ \\
\hline $\begin{array}{l}\text { Accepted: } \\
23.06 .2015\end{array}$ & $\begin{array}{l}\text { argues, 'policy and practice needs to consider social, economic and } \\
\text { environmental implications for all life'. The field of urban planning }\end{array}$ \\
\hline Key words: & $\begin{array}{l}\text { this. Key issues of democracy and participation in } \\
\text { cy making at local and regional level; the role of the }\end{array}$ \\
\hline $\begin{array}{l}\text { holistic; engaging; community; } \\
\text { complexity; creativity; } \\
\text { democracy }\end{array}$ & $\begin{array}{l}\text { private sector and the balance of markets, government and civil } \\
\text { society; and a containerized approach by government results in } \\
\text { much urban planning failing to recognize future consequences of } \\
\text { current choices. Democracy needs to change to meet the } \\
\text { convergent social, economic and environmental challenges. } \\
\text { McIntyre-Mills recommends 'both centralized controls to protect } \\
\text { the global commons and decentralized engagement to test out our } \\
\text { ideas'. Urban planning also will only succeed if it recognizes that } \\
\text { 'we need to be the subjects not the objects of other people's } \\
\text { designs' (McIntyre-Mills). However, participatory design is } \\
\text { complex and difficult and, while digital communication can } \\
\text { potentially include more voices, like any engagement it works best } \\
\text { when complementing other processes and 'built around the needs, } \\
\text { goals, and concerns of the potentially engaged,' (Leinghninger). } \\
\text { Sarkissian therefore argues that urban planning needs to take a } \\
\text { holistic approach, 'taking into account multiple layers and } \\
\text { components of social systems' and to be long term focused. This } \\
\text { paper explores the means to do that. }\end{array}$ \\
\hline
\end{tabular}

\section{Introduction}

Aboriginal peoples believe 'How I live will determine the quality of the landscape' (McIntyre-Mills, 2010, p.8) and that the quality of the environment and our relationships with others directly determines quality of life and happiness (Ibid, p.8).

\footnotetext{
*Correspondence: barbara.dickens@sa.gov.au
} 
Increasingly, communities and their elected members see our cities as unaffordable, too vehicle dependent, resource intensive to build and maintain, and leaving residents 'emotionally and physically compromised' (Condon, 2008, p.2). 'And yet, all manner of experts can never answer the question: how do we want to live?' (Beck, 1999, p.22). With 60 percent of the world's population predicted to live in cities by 2013 - 5 billion people, compared with 3.6 billion in 2013 (Bouton et al., 2013, p.1) - it is a question which is becoming increasingly more crucial to answer.

Stoker said that we live in 'a complex, fragmented urban world' (as cited in Pierre, 2000, p.92) where 'Land use, employment, leisure and welfare in urban areas are profoundly shaped by the forces of the private market' (Ibid, p.92). It is a world where 'global problems are generated at the local scale and should be solved there too' (Condon, 2008, p2) and a world in which every being has 'the right to live a decent, sustainable way of life which is currently being undermined by the state and the market' (McIntyre-Mills, 2010, p.7).

McIntyre-Mills argues that 'policy and practice needs to consider social, economic and environmental implications for all life' (McIntyre-Mills, 2010, p.5). Identifying our creativity as the key to a better future, she asks 'Can we design systems and technologies that sustain a future environment, or will we design systems that destroy our future?' (Ibid, 2010, p.4).

This raises the question of whose creativity can and should be harnessed, and how. It is neither a task for government alone, nor for experts across the public and private sectors, to determine how communities and individuals should plan the environment in which to live. Anthony Giddens argues that 'both social engagement and steering from above will be needed' (McIntyre-Mills \& de Vries, 2011, p.77).

Recognising this, the South Australia Government formed the Urban Renewal Authority (which trades as Renewal SA) to 'present a fully integrated approach to urban development' (Weatherill, 2012a). Launching the Authority in March 2012, the State Premier said this represented 'a new way of planning for residential and industrial communities in South Australia' (Ibid). The Premier also said that community engagement would be central to all urban renewal projects (Weatherill 2012b:11), and therefore a key factor in achieving sustainable urban development.

How? Urban planning has taken many forms over the past 150 years, with potentially increasing opportunities for public participation, while the form of public participation has changed even more rapidly with the advent of modern communications technology. Both urban planning and public participation have been influenced by other factors.

In order to explore effectively a range of approaches to public participation in urban planning, discuss engagement principles and make key findings and recommendations towards attaining a holistic approach, we first need to examine the context for urban planning. At the same time, what is meant - or understood - by sustainable development also requires clarification.

\section{The Context for Urban Planning}

Approaches to urban planning and their outcomes are affected by key issues of democracy and participation in public policy making at local and regional level, the role of the private sector and the balance of markets, government and civil society. 


\section{Key issues of democracy and participation in public policy making and delivery}

Neoliberal reforms in the 1970s, influenced by the customer-oriented cultures of the private sector, focused on reducing government expenditure, a major consequence being 'subordinating social policy to economic competitiveness' (Hoggett, 2009, p.157).

A current example in South Australia is the State's policy on establishing new schools. A school will not be built until demand exists. This affects planning for the Renewal SAmanaged Bowden urban renewal project in Adelaide in that, despite projected demand, a new school cannot be built until the residents are in situ; yet some potential residents have expressed reluctance to purchase without assurance that the need will be met. If current policy prevails, the project master plan requires sufficient flexibility to include a school at an advanced stage of the site's development. If community buy-in, literally, through residential purchasing, is not achieved, the development could run the risk of being seriously compromised.

The view of potential residents is not unreasonable, and is shared by the existing adjacent community, which considers the new development as its neighbourhood. Indeed, to 'create a fully inclusive nation, we must ensure that all people live in communities of opportunity places with quality schools ... quality house choices, public transportation, safe and walkable streets, services, parks, access to healthy food and strong social networks' (Rogers, 2012, p.15).

The political system focus on short-term rather than long term benefits (Hoggett 2009, p.161) is compounded by neither governments nor citizens appearing to be willing to 'face up to their own responsibilities for collective problems' (Ibid, p.161), while globalization of economic, technological and political developments is providing what Stoker terms 'a homogenizing stimulus' (as cited in Pierre, 2000, p.92) for city governments to look elsewhere for ideas.

South Australia exemplifies this. The previous administration has been criticized for its 'narrow vision for city planning, its deliberate disengagement from the public in planning processes, its failure to address major longstanding urban planning problems, and its dumbing down and weakening of existing planning controls' (O'Leary, 2011, p.18).

O'Leary states that instead of developing 'a credible overarching vision for Adelaide' (O'Leary, 2011, p.18), the Rann State Government was 'more intent on implementing a string of showcase development projects around the city' (Ibid, p.18) some of which do not meet wider strategic needs' (Ibid, p.8). As McIntyre-Mills observes, 'Short-term profits are made at the expense of future generations' (McIntyre-Mills, 2014, p.9) while 'governments focus on political survival, rather than addressing the social, economic and environmental crises' (Ibid, p.9).

All of this, and a containerized approach by government - illustrated by there being no less than five different planning reports commissioned by State or Local Government for Adelaide between 2011 and 2013 'competing for vision splendid' (Williams, 2013, p.66) - results in much urban planning failing to recognize 'the relationship between our choices now and their consequences tomorrow' (IDC, 2012, p.2) particularly in terms of sustainability.

What then is sustainable development? The Brundtland Report of the World Commission on Environment and Development defines it as 'development that meets the needs of the present 
without compromising the ability of future generations to meet their own needs' (Condon, 2008, p.5, Chapman, 1996, p.90).

Chapman raises the challenge of designing and managing human settlements in a way that 'people may live at a decent standard based on sustainable principles' (Chapman, 1996, p.90) of futurity, environment, equity and participation. Chapman also notes that one of the outputs of the Rio Earth Summit in 1992 specified that 'the integration of land use and planning, energy and conservation, waste management' (Ibid, p.90), among other issues, would be 'examined at a local level in consultation with local people' (Ibid, p.90).

In consulting at the local level it is crucial too to recognize that choices made about land use, water and energy have implications for the wider region as well as local well-being and therefore that those choices be transparent (McIntyre-Mills, 2012, p.465).

\section{The eternal triangle - markets, government and civil society}

More recently, the Washington Consensus is attributed as a major cause of global failure 'to generate sustained economic growth, poverty reduction and fair outcomes' (Held, 2004, p.11).

Held criticizes it on the grounds that it 'underplays the role of government, the need for a strong public sector, and the requirement for multilateral governance' (Held, 2004, p.9-10). He warns that 'Leaving it to markets on their own to resolve problems of resource generation and allocation will perpetuate many deep-rooted economic and political difficulties' (Ibid, p.15).

Held advocates the Washington Consensus model (in which privatization, minimal regulation, free trade and movement of capital are key features) be replaced by a social democratic agenda characterised by 'Strong civil society, state-led investment strategy, strong public sector [and] priority investment in human and social capital' (Held, 2004, p.34).

This approach lies behind the formation of Renewal SA, but is not welcomed in all quarters. Views differ widely on the role of markets, government and civil society. The Property Council, in its Adelaide: City of Lights report, advocates 'a new governance model for Adelaide' (Johnston, 2012, p.77) transferring 'a significant amount of control and responsibility' (Ibid, p.77) from local to state government (Renewal SA), sparking debate on 'whether we should be allowing the development industry to drive the strategic planning of the state, often behind closed doors' (Ibid, p.77). Renewal SA's predecessor, the Land Management Corporation, relied extensively on public private partnerships (PPPs) for planning and delivery of its projects.

Others defend the private sector saying it 'can't be blamed for filling a vacuum created by a lack of government leadership and investment in the level of community-informed planning' (Johnston, 2012, p.77) while yet others call for more industry contribution via 'establishment of new infrastructure funding arrangements and local stewardship models that enable developers, local businesses and residents to invest in, manage and market their own neighbourhood precincts' (Ibid, p.77).

South Australia Planning Minister, John Rau, says his government's current planning policies "upset "vested interests" in the development industry' (Mannix, 2014, p.1); its moves to favour inner-city infill while limiting greenfields developments in the outer metropolitan 
areas being 'a direct attack on their business models' (Ibid, p.1) because the policies change the way the city evolves. Ironically, the previous South Australian Government's Planning Minister, predicted in 1999, as Adelaide struggled with growth in its outer areas, that 'For the community, continued urban expansion may lead to increased social, economic and environmental costs' (Ibid, p.2014).

Whatever the approach, Adelaide has been advised by an England-based geographer and 'localism' strategist to 'avoid narrow economic definitions of success, and rigid governance structures that are no longer affordable, and which stifle experimentation and creativity' (Johnston, 2012, p.77).

The power of the private sector in urban development and its reluctance to innovate in the interest of sustainability has long plagued Adelaide. It required the State Government to lead the initiative at the Lochiel Park Green Village, supporting the four developers through training and incentives to incorporate innovative, ecologically sustainable development technologies (Hurley, 2010, p.10) new to Adelaide that constrict their profit margins and increase their risk.

Economic realities do need to be recognized - ideally with sustainable, integrated development assuming both 'the short-term benefits of financial profit and the long-term benefit of economic sustainability to be of equal importance' (McIntyre, 2003, p.348).

Held acknowledges that 'there will be conflicts between economic development and the strengthening of civil society' (Held, 2004, p.13) and that 'societies need significant measures of autonomy to work out their own ways of managing these conflicts' (Ibid, p.13-14). He also emphasises that we need to realize that we survive not through conflict and competition but 'because we are complementary to each other' (McIntyre-Mills \& de Vries, 2011, p.219).

\section{The dis-integrated city - the fallout of poor planning}

How can urban planning therefore be approached? It appears that 'our ordinary problem-solving methods don't work when we are designing, planning and building sustainable communities' (Condon, 2008, p.2-3). Ironically, while succeeding technically in improving individual elements of the urban landscape, such as buildings, roads, open space and water recycling systems, 'taken together they fail in crucial ways' (Ibid, p.3).

Expansion of cities is 'turbo-charging the world's economic growth' (Bouton et al., 2013, p.1), but economic growth itself does not automatically deliver a better quality of life; instead it often harms the environment and many cities are having to take remedial action to fix the problems caused by growth (Ibid, p.5).

In creating 'sprawling suburban landscapes' (Condon, 2008, p.3) over the past 50-60 years we have provided 'a collection of impressive solutions to very narrowly defined problems rational details adding up to an irrational whole' (Ibid, p.3). As Condon concludes, 'All of these elements, however exquisitely designed ... do not add up to a whole worthy of the word community' (Ibid, p.3).

The Integrated Design Commission (IDC) of South Australia held a similar view, saying 'It is not good enough for a city to look good. It also has to perform well' (IDC, 2012, p.1) and, in talking about planning for inner-Adelaide, emphasised that 'The right decisions reflect the values and beliefs of the people who live, work and play here' (Ibid, p.1). The IDC also 
recognised that economic prosperity, the earth's health and our communities' wellbeing 'are not mutually exclusive agendas' (Ibid, p.2). Prior to being disbanded by the State Government in 2012, the IDC proposed that design-based methods of urban planning 'offer a way of meeting each of these objectives' (Ibid, p.2).

Design by experts has played a major role in the past, with poor outcomes, as Condon describes. The modern 'dis-integrated city' (Condon, 2008, p.xiv) in the developed world, with its segregated land uses, is characterized by big box shopping centres isolated from enclaves of single-family residences in dead-end streets. It has lost the connectivity of the web network of streets and commercial activity acting as a 'thread binding the fabric of the city' (Ibid, p.xiv) which characterizes older cities.

We are now challenged with 'changing the world of the 5-minute drive to the world of the 5minute walk' (Condon, 2008, p.45) not only in physical terms through design but in changing mindsets - of planners, designers, retailers residents and 'stubborn automobile addicts' (Castells, 1996, p.396). This emphasizes that 'The challenges of governance need to be addressed by working across disciplines' (McIntyre-Mills, 2014, p.11) to avoid the silo approach working in 'limited disciplinary paradigms that can profit at the expense of others' (Ibid, p.11).

Brendon Gleeson perceives an attitude within western society as the underlying problem. Quoting Clive Hamilton's phrase "growth fetish' (Gleeson, 2013, p.1), he attributes the crisis of urban sustainability to accumulation and states that the problem is not accommodating growth but 'our slavish pursuit of growth itself' (Ibid, p.1). He declares that we now have urban sprawl 'in every possible physical form - from low-density suburban to the vertical sprawl produced by market-driven compaction' and that 'It is a fallacy to describe the latter as sustainable' (Ibid, p.1).

The disintegration of cities goes far beyond disconnected streets and the argument of low versus high density. Detroit, described as 'a half-ruined city' (Toohey, 2012, p.29), 'ghetto' and 'among America's five most violent cities' (Ibid, p.29) has gone from economic prosperity to poverty within three decades. Half its houses are 'abandoned, burned out or bulldozed' (Ibid, p.29) and it lacks basic community services. Most of its people have no prospects to enable them to leave or improve their lives; instead they have 'no dignity, no pride or respect' (Ibid, p.29).

Detroit exemplifies the 'systemic disempowerment of inhabitants' (Gordon \& Koo, 2008, p.204) of cities 'at the intersection of myriad financial interests and government jurisdictions' (Ibid, p.204-205).

Any approach to better planning to resolve this complex mess and balance the state, market and society, to provide a sustainable environment requires, as McIntyre-Mills says, 'a democracy/governance cycle that spans conceptual, spatial and temporal boundaries' (McIntyre-Mills, 2010, p.8) and 'working across nested systems and ensuring that the people who are to be affected are included' (Ibid, p.8) if we are to succeed in supporting the global commons (McIntyre-Mills \& DeVries, 2009, p.175).

Former South Australia Premier, Mike Rann echoes Giddens in saying cities need revitalizing through 'a plan drawn from its citizens but delivered through strong leadership' (Rann, 2012, p.7-8). 
In Australia, 'after years of neglect' (Rann, 2012, p.8) a 'renewed national engagement with urban policy' (Ibid, p.8) is emerging. That the Australian Federal Government recognises 'Our cities play a pivotal role in securing the social, economic and environmental wellbeing of our nation' (Australian Government, 2011a, p.2) and has committed to a reform process, issuing a new national urban policy 'for a productive, sustainable and liveable future' (Ibid, p.3), is encouraging.

Capital and regional city planning systems must: meet nine criteria focused on sustainability and wellbeing indicators in Australia's Liveable Cities Program (Rann 2012, p.9-10, Australian Government, 2011b, p2, p11); adhere to policies on climate change and urban development; and be guided by the first Urban Design Protocol for Australian Cities containing broad principles for urban design, and the State of Australian Cities 2011 report which identifies seven liveability measures (Australia Government, 2011c, p.141). These all contribute to the context for urban planning.

Essentially, the Urban Design Protocol is founded on 5 pillars: productivity; sustainability; liveability; leadership; and design excellence. Under Leadership and Governance it has two key principles relevant to this paper - Engagement and Custodianship - each of which has several attributes to help achieve world-class urban design (AG, 2011b, p.11). (Appendix $1-$ Resources for participation).

Three key Engagement attributes are identified - to engage with relevant stakeholders being: it acknowledges that urban design is primarily about creating places for people; it engages people in the development of their community; and it adopts a multi-disciplinary and collaborative approach to planning and design (AG, 2011b, p.11).

Four key Custodianship attributes are identified - to consider custodianship and maintenance over time - being: it recognizes that communities, environments and cities are continually evolving and adapting; it considers the wider environmental, social and economic costs and benefits of development, operations, maintenance and disposal; it ensures that the design of a place is appropriate for its ongoing maintenance, operations and upkeep; and it incorporates strategies to reduce and adapt to climate change (AG, 2011b, p.11).

In its State of Australian Cities 2011 report the Australian Government identifies a set of 17 attributes that make a city liveable - drawn into 7 broad groups: safety; accessibility; affordability; health; diversity; environmental sustainability (which includes climate change); and quality design and amenity. (AG, 2011c, p.141). (Appendix 1 - Resources for participation).

Accessibility identifies a broad range of services and opportunities essential to citizen wellbeing, while the health attribute makes particular reference to the need for a healthy climate through a clean, well-maintained and unpolluted urban environment with a wide range of recreational opportunities that encourage social interactions. The environmental sustainability attribute makes particular reference to the need for good approaches to climate change.

In December 2009 the Council of Australian Governments (COAG) agreed on a national objective and nine criteria to ensure Australian capital cities are globally competitive, productive, sustainable, liveable, socially inclusive and well placed to meet future challenges. It was noted at the COAG meeting that 'the criteria will ensure our cities have 
strong, transparent and long-term plans in place to manage population and economic growth; plans which will address climate change, improve housing affordability and tackle urban congestion' (AG, 2009, p.8).

A competitive, merit-based grant program, the Liveable Cities Program is administered by the Australian Government Department of Infrastructure and Transport to 'help improve the planning and design in major cities and major regional cities that are experiencing population growth pressures, and housing and transport affordability pressures' (AG, 2011d, p.4). It is particularly supportive of development projects that 'drive urban renewal and strategic urban development that contributes to improving the productivity, sustainability and liveability of our cities' (Ibid, p.4). Ten objectives support these three goal areas (Appendix 1 - Resources for participation).

\section{The need for Expanded Pragmatism}

Urban planning has been the subject of much debate in professional and academic circles, with different perspectives on whether it is an art of science - based around 'the importance of rational/emotional, technical/social and singular/multiple approaches to current and future issues such as sustainability' (Sarkissian \& Hurford, 2010, p.5).

The either/or thinking underlying these debates is a fundamental problem. Urban planning cannot succeed if it occurs in isolation to the people at the receiving end of its plans; that is 'we need to be the subjects not the objects of other people's designs' (McIntyre Mills, 2010, p.7) and therefore be involved in developing them. As Beck says in A World at Risk, 'This is a matter no longer of hospitality but of the right of the "living the side effects" of the risk decisions of others to have a say in those decisions' (Beck, 2007, p.191).

Beck is not alone in his view. Sarkissian states 'Community engagement for sustainability, like food, personal safety and shelter, is foundational' (Sarkissian et al., 2009, p.76), while McIntyre-Mills observes that 'promotion of a healthy environment needs to be placed as a central assumption of planning' (McIntyre-Mills, 2003, p.348).

McIntyre Mills and De Vries expand on this, saying, 'Participation, social construction and valuing the experiences of those who are to be at the receiving end of decisions are important for wellbeing' (McIntyre-Mills \& de Vries, 2011, p.104). McIntyre-Mills advocates that these experiences can be shared through 'listening, telling stories and creating scenarios' (McIntyre-Mills, 2010, p.4). That 'can create shared meanings where none existed before' (McIntyre-Mills \& de Vries, 2011, p.80) while also enabling connections and enhancing creativity (Ibid, p.80). Through this participatory design, we can 'ensure that co-created indicators take into account the passions and emotions of the people' (McIntyre-Mills, 2012, p.465).

How specialists in a wide range of fields involved in urban planning policy are able to 'think about our thinking' (McIntyre-Mills 2006, as cited in McIntyre-Mills \& de Vries, 2011, p.86) through the process of 'unfolding' values with the people affected by the policy decisions, at the same time covering all social, cultural, political economic and environmental dimensions, is crucial (Ibid, p.86). They need to understand 'how the micro-culture of the locality will articulate with the macro-culture regionally, nationally and internationally' (Chapman, 1996, p.174) because 'the nature of the built environment that we have locally will have impacts upon the world in general' (Ibid, p.174). 
Gradually, the focus of many urban and social planners, architects and governments is also changing from seeking individual solutions to identifying problems and understanding how everything inter-connects (IDC, 2012, p.1).

An investigation of decision-making in eight of the world's most successful cities by the Grattan Institute (an independent think-tank for Australian public policy) argues for people to be involved in making decisions about their neighbourhood (Grattan Institute, 2012, p.28). Its research reveals that 'Helping to shape the future of the local area creates a sense of stewardship and promotes connection with other residents' (Ibid:28).

However, participatory design is complex and difficult (McIntyre-Mills, 2003, p.345). How does one identify all who are to be included in the urban planning process and enable the dialogue?

Two decades ago many commentators noted that public involvement was 'still based upon social class' (Chapman, 1996, p.176) with most people affected by development proposals not knowing where to start in understanding a development project's impact (Ibid, p.176). While it can be argued this has improved through increased awareness, transparency and engagement opportunities, the powerless remain excluded (McIntyre-Mills \& de Vries, 2011, p.204, Florini, 2003, p.87-88).

McIntyre-Mills also observes that 'There is evidence that many desire more environmentally sustainable lives, but little is known about the influence on choices around the management of land, water and food that affect the environment. Government response to human wellbeing is often based on economic development' (McIntyre-Mills, 2014, p.7). She therefore recommends that, the future focus of research in relation to climate change be on 'The inherent link between engagement in civil society and community wellbeing (rather than the economic bottom line)' (Ibid, p.7). The same could be said in relation to urban development.

Expanded pragmatism - 'the capability to think in terms of the consequences for self, others (including sentient beings) and future generations of life' (McIntyre-Mills \& de Vries, 2011, p.328) also is needed. Encouragingly, this is included in the Urban Design Protocol for Australian Cities principles (Australian Government, 2011b, p.11). (Appendix 1 - Resources for participation).

In drawing many voices into the discussions how can planning be expedient, ensure that all voices are heard and respected and the outcomes agreed? Reflection on past approaches to urban planning helps towards answering that question.

\section{The chequered history of public participation in urban planning}

Urban planners and local government today often encourage public participation in planning, and it is also often mandated by law (Cooper \& Balakrishnan, 2013, p.174) but that has not always been the case and the level of participation has varied considerably - and continues to do so.

Cooper and Balakrishnan use Arnstein's ladder of participation as a 'guiding typology' (Ibid, p.174) (Appendix 1 - Resources for participation) towards understanding the level of citizen participation in different planning models. Ranging from manipulation at the lowest rung of the ladder to citizen control at the highest rung, it works in a similar way to the International Association of Public Participation (IAP2) spectrum discussed later in this paper, which 
ranges from a purely informing level through to community empowerment (Appendix 1 Resources for participation).

\section{Blueprint planning}

Cooper and Balakrishnan observe that 'Modern practices in urban planning are deeply rooted in planning theories of $19^{\text {th }}$ Century European thinkers' (Cooper \& Balakrishnan, 2013, p.:174) who viewed planning as 'an apolitical and technical enterprise in which planners used scientific rationality and reason to design ideal blueprints for city development' (Ibid, p.175). Often called "blueprint" planners, they aimed 'to influence society mainly through the alteration of built environments' (Ibid, p.175) rather than by programmatic or policy-based approaches. Their blueprints purposely aimed not to involve the public in the design process and were intended 'to unilaterally alter urban communities' (Ibid, p.175).

\section{Synoptic planning}

With the growth of cities and greater mobilization, a new planning paradigm was seen to be needed by the mid-20 ${ }^{\text {th }}$ Century to understand dynamic urban systems (Cooper \& Balakrishnan, 2013, p.175). In the late 1950s the synoptic method (also referred to as systems planning and rational-comprehensive planning) emerged. It sought to assess city needs more comprehensively and find policy and planning solutions to address those. While the synoptic planning model 'further professionalized planners as the technical experts' (Ibid, p.175) governments started mandating public consultation into the process, which followed a sequential path from data collection, through analysis to decision-making (Ibid, p.175).

Cooper and Balakrishnan observe that the scientific approach gave the appearance of progression from the blueprint approach, but that the level of public participation was limited to 'token consultations on predetermined plans' (Cooper \& Balakrishnan, 2013, p.175).

Synoptic planning also neglected to acknowledge and reflect different communities and interest groups in cities and to 'address the issue of equal representation' (Cooper \& Balakrishnan, 2013, p.175), which sparked challenges by both professionals and community activists in the late 1960s and the 1970s and led to several planning models emerging, articulated by modern thinkers. Three key ones were: advocacy planning in the 1960s; transactive planning in the $1970 \mathrm{~s}$; and transformative planning in the $21^{\text {st }}$ Century (Ibid, p.175).

\section{Advocacy planning}

Paul Davidoff's Advocacy and Pluralism in Planning (1965) articulated advocacy planning as 'a vision of planning as a collaborative tool for planners and communities to address inequality in cities' (Cooper \& Balakrishnan, 2013, p.177-178). It had emerged through involvement by urban planners in the civil rights movement as 'an organized response to the displacement of low-income communities of colour by federal urban renewal schemes in cities throughout the United States (Ibid, p.175) The War on Poverty, particularly the Model Cities Program, bolstered it further.

Fundamentally it recognized values, diversity of interests, the need for neighbourhoods to create their own plans, and the need for planners to consider the social consequences of physical planning (Cooper \& Balakrishnan, 2013, p.176). In essence, the difference from previous planning approaches, in principle, was a move from 'the critique of preconceived 
plans' (Ibid, p.176) to involving a range of stakeholders in developing plans.

\section{Transactive planning}

In developing the transactive planning model in the 1970s, Friedmann recognized the need for planners to know community needs and concerns and for community to know about planning policy and government power structures in order to meet and transact towards planning outcomes. In transactive planning community empowerment is an end in itself, rather than the means to a planning outcome. The role of planners is seen as 'sensors who receive information and feedback from stakeholders and incorporate their ideas, concerns, and needs into plans' (Cooper \& Balakrishan, 2013, p.176). This model is still evident in the approach by South Australian government infrastructure agencies today.

\section{Transformative planning}

Transformative planning 'leverages the organizing power of community-based groups to transform traditionally excluded groups into the leaders of planning processes' (Cooper \& Balakrishnan, 2013, p.176). It values the contribution of local knowledge to planning outcomes and aims 'to move planning from a physical design field to a politically and socially conscious discipline' (Ibid, p.176). Transformative planning has led to the rise of The Right to the City movement, which calls on urban residents 'to harness their collective power to rethink and recreate urban planning processes and the development of cities' (Ibid, p.176) - a fine objective but what of the reality?

\section{The current reality of Public Participation}

\section{Announce and defend}

Sadly, many projects still 'follow a familiar and well-trodden path to poor outcomes' (Twyford et al., 2006, p.51) by presenting a solution developed by technical experts - a blueprint - for comment. The outcome invariably leads to an unproductive cycle of public meetings where the people who hate the idea 'make things unpleasant by heckling the project team and anyone else who doesn't agree with their views' (Ibid, p.51-52). This also exemplifies the traditional 'town hall model' (Cooper \& Blakrishnan, 2013, p.177) used for most planning meetings as 'a culturally inflexible space in which public participation becomes "token", temporally discontinuous, limited to responding to existing agendas, and with limited government accountability’ (Ibid, p.177).

This has been the case for years in Australia, with 80 percent of planning for infrastructure development projects occurring within government (Rann, 2012, p.29). Technical experts develop options, select a preferred option and present it for feedback. This 'announce and defend' method much used by the South Australia Government has caused community outrage (Liebrucks, 2010, p.12).

Simply including the community early to identify the problem, identify and resolve issues in developing options, and deciding on the preferred option avoids a destructive process and poor outcome. However, in drawing many voices into the discussions how can planning be expedient, ensure that all voices are heard and respected and the outcomes agreed? 


\section{Citizens' Jury}

Citizens juries are useful to randomly represent diverse community interests through a few in deciding among options for complex areas and challenging the experts presenting the options. Citizens jury reports are made available to technical experts, the media and the public as well as Government.

The State Government opted for a citizens' jury of 40 South Australians to review the 'array of competing visions' (Williams, 2013, p.66) for Adelaide. The jury received about 50 hours of briefings on issues facing the central business district (CBD), in a process run by the notfor-profit NewDemocracy Foundation and produced recommendations by the end of 2013 for final decision by Parliament (Ibid, p.4).

The Australian Centre for Social Innovation (TACSI) evaluated the process of this first venture by the State Government into citizens' juries, based on the views of jurors, bureaucrats, experts, special interest groups and facilitators. Overwhelmingly the research revealed that citizens were viewed differently following the citizens' jury, as 'knowledgeable and capable, with the ability to inform themselves, make decisions, and learn to think in new ways' (TACSI, 2014, p.4) and the jury had attracted people not previously engaged in government decision-making and engaged with them in a different way.

Although views among bureaucrats were equally split on whether citizen-driven judgement could bring value to public decision-making (TACSI, p.4), the majority of respondents in the research 'saw extraordinary value in engaging citizens in democratic decision making' (Ibid, p.43), and the Premier made an election commitment to host at least two more citizens' juries during his term.

\section{The iterative design Charrette}

One popular engagement process currently used for extremely complex design projects with multiple stakeholders is the design charrette, used successfully to develop the site plan for the Bowden development in Adelaide. It challenges participants 'to collaboratively solve what appears to be an impossible problem in what they may think is an absurdly short time' (Condon, 2008, p.1).

A strength of the charrette process is its capacity to 'make citizens with a stake in their community ... members of the design team' (Condon, 2008, p.13) where 'Their own empathy, understanding and compassion fuel the creative collaborative process and allow the group to transcend the status quo' (Ibid, p.13).

Charrettes are an ideas forum, 'offer the unique advantage of giving immediate feedback' (Liebrucks, 2010, p.10) and a final decision involving all participants (IAP2, 2006b, p.49, Stein, 1992, p.51). They also enable citizens to design, proving that design is 'more a way of thinking than a specific set of technical skills' (Condon, 2008, p.57-58).

However, charrettes also are cost, time and labour-intensive in preparation (Stein, 1992, p.51) and risk excluding time-poor citizens from participating. Another weakness of charettes, and other forms of traditional engagement, is that they involve only a representative few of the community. With Bowden, the charrette followed an appreciative enquiry process of facilitated workshops to develop the vision and initial planning ideas. While many charrette participants participated in the entire process and speak highly of it, the need remains to include more voices. 
Similarly, on-site community open houses, while offering the opportunity for community to discuss issues and ideas directly with the specialist planning team also are limited by time and physical constraints. They need to be complemented by other forms of engagement to include more people and extend the iterative process.

\section{Traditional Planning Limitations}

Cooper and Balakrishnan also conclude that 'in spite of the clear evolution of both public participation and authority in planning models over some 150 years, many elements of blueprint and synoptic planning 'that run counter to participatory planning' (Coooper \& Balakrishnan, 2013, p.176) remain, due to several factors, chiefly: power disparities; emphasis on physical design elements and neglection of facilitation skills to engage and incorporate social elements, public opinions and local knowledge; and continued challenging of planning practices by pluralism - meaning 'planners are often idealized as the experts on serving a monolithic public interest' (Ibid, p.176).

Cooper and Balakrishnan also observe that 'political complexity often creates situations where the interests of a powerful few ... dominate and/or create gridlock' (Cooper \& Balakrishnan, 2013, p.176).

They conclude that the crux for planning, irrespective of the planning paradigm, is that 'the quality of the outcome is dependent on the participation of citizens' (Cooper \& Balakrishnan, 2013, p.177). Quoting Bourgoin et al, in reference to the Rio Earth Summit of 2012 in which local land-use planning was part of the agenda, they stress that 'The participation process should be driven by the people affected by planning decisions and who can provide knowledge that fits local context' (Bourgoin et al., 2012, as cited in Cooper \& Balakrishnan, 2013, p.177). To optimize public participation therefore, they state that communities and planners need to adopt paradigms and tools which 'democratize the planning process' (Ibid, p.177).

Having identified weaknesses in the more traditional engagement processes used historically within planning, Cooper and Balakrishnan ask what potential there is for online tools to make planning and decision-making in the urban planning arena both more engaging and accessible. In doing that, they stress that online tools are not simply moving paper-based methods online; instead they perceive the wide range of information and communications technology (ICT) 'enabling the provision of open source information, the collection of data from the public, greater access to democratic processes, forums for collaboration, and communication among urban stakeholders and government' (Cooper \& Balakrishnan, 2013, p.177).

\section{The move to E-Participation}

Technological advances have fuelled a social media revolution with ever-increasing potential options to include more voices. Specialists advise that online engagement also works best when integrated with other processes and building on existing relationships (Cook, 2008, p.99). As with offline engagement it must be 'built around the needs, goals, and concerns of the potentially engaged, not just the engagers' (Leinghninger, 2012b, p.4).

Engagement specialists also highlight the importance of using engagement processes that ensure stakeholders no longer have 'the luxury of maintaining their own narrow position' (Condon, 2008, p.13). As McIntyre-Mills argues, diversity matters but 'only to the extent that 
diversity and freedom do not undermine the future of the next generation of life' (McIntyreMills \& de Vries, 2011, p.197).

So swiftly is social media changing, it is described as 'like trying to catch lightning in a bottle' (Gillin, 2009, p.:xxii) as its users share opinions through personal publishing (Ibid, p.4-5). 'Social media is about ordinary people taking control of the world around them and finding creative new ways to bring their collective voices together to get what they want. Whether you like it or not, it is the world to which institutions must adapt' (Ibid, p.4) Gillin states.

Social networks provide 'a much richer environment in which conversations can take place' (Gillin, 2009, p.106) with networks for nearly every age, interest and geographic region (Ibid, p.98). However, the vast range of options means 'strategy is vital to sorting through them' (Ibid, p.21). Factors such as age come into play. Conventional means are more likely to succeed with the over 50s than the under 20s (Ibid, p.25), while for children 'social networks have become the online equivalent of the local mall' (Ibid, p.107).

Can social media be a planning tool for engagement in its own right? It has been described as 'the new means for efficient and effective community engagement and collaboration' (Liebrucks, 2010, p.6).

Social media such as Meetup exist 'so that people can use the Web to get off the Web. It strives to connect people in their geographic area who share similar interests' including politics (Gillin, 2009, p.140) to meet up 'using the old-fashioned way - in person' (Ibid, p.140). 'The objective is to make it easy to create physical get-togethers' (Ibid, p.140).

One application of social media in urban planning is the use of QR codes - accessed free through a mobile telephone application - to link the past, present and potential future for a site, or elements of it, and invite a conversation which, like charrettes, can be both online and face-to-face. It is proving increasingly successful for planning public open space such as a reserve, mall or streets, where it is impossible to identify all users.

Social media therefore can be useful to create conversations on planning issues to feed into other online engagement tools used for urban planning. It is particularly useful to engage young people - the next generation - so often excluded from the planning process.

Children have a different objective and cognitive view of the world than adults, and also 'may have a richer perspective on their local environment' (Cook, 2012, p.2) through their 'smaller geography' (Ibid, p.2) Gaining their 'different experiences, perceptions and meanings attached to their cities, spaces and places' (Ibid, p.2) through visual methods - to which social media lends itself - is often easier than more traditional consultation (Ibid, p.4). Children also have an uninhibited, 'unique ability to tap into creativity and dream about the future' (Sarkissian \& Hurford, 2010, p.159-160).

\section{Spaceshaper}

Another online engagement tool proving successful for meaningful engagement of children is Spaceshaper. Specifically developed for planning to improve an existing public space with which participants are familiar, Spaceshaper provides immediate feedback to input, informing dialogue and decisions. It was recently trialed in South Australia through a 
partnership of local government, state government and the SA Council for the Care of Children.

\section{Second Life}

Three-dimensional visualizations have long been useful urban planning tools. They help to address community concerns about space, density, scale and linkages and can assist in identifying and exploring technical problems. Cooper \& Balakrishnan recommend them as elements of accessible e-planning websites for local government, together with technical reports, information about planning systems, laws and procedures, and the facility for individuals to engage with planners and other stakeholders through the website (Cooper \& Balakrishnan, 2013, p.177).

Highly controversial, because of its virtual-reality gaming roots, Second Life in particular has much value to urban planning as it 'attempts to mimic the real world through a threedimensional experience' (Gillin, 2009, p.134). Users' characters can interact in 'destinations representing different communities of interest' (Ibid, p.134) in an experience 'closest to resembling genuine human reaction' (Ibid, p.134).

It also enables participants to experience different characters, their experiences and viewpoints, and 'unquestionably has value as a medium for virtual meetings, where presentations can be combined with discussions and ad hoc groups can form' (Gillin, 2009, p.135-6). Its appeal to play has particular potential to engage children, but online games also have adult appeal and provide 'a chance for citizens to test their knowledge or come up with their own solutions to public problems' (Leinghninger, 2012, p.23)

The 3-D immersive game Immersive Chinatown was developed specifically 'to enhance participation in the master planning of Boston's Chinatown' (Cooper \& Balakrishnan, 2013, p.178) in 2010 by the Engagement Lab (EGL) of Emerson College, Boston, USA, which produces social media and game technologies for urban planning. Its success is attributed in part to its being a strategic partnership across local government, a local not-for-profit, software company and the EGL.

Although virtual worlds are in the experimental stage as far as urban planning is concerned, Gillin observed in 2009 'a few early successes indicate they merit watching' (Gillin, 2009, p.136). Since then their development and use has progressed at an increasing rate.

\section{The Virtual Charrette}

The success of charrettes has stimulated development of the virtual charrette, which can be held concurrently with a live charrette. Liebrucks has explored the feasibility of a virtual charrette in South Australia, for the Property Council.

She notes that to succeed, virtual charrettes must emulate physical charrette collaboration through social media (Liebrucks, 2010, p.15). Liebrucks focuses on three - Facebook, blogs and micro blogs - based on their accessibility and success for Adelaide community groups 'to gain force behind community activism' (Ibid, p.12).

Spacing Toronto enabled a virtual charrette in group blog format for the new Bathurst Bridge, through an online dialogue of words and images. A key success factor was engaging citizens early in the process (Liebrucks, 2010, p.16). 
Hub2, an initiative of the City of Boston, uses Second Life's 'entirely user-created virtual world' (Gordon \& Koo, 2008, p.205) platform to create a sequence of simultaneous physical virtual charrettes, with 'a physical moderator and virtual designer orchestrating deliberation' (Gordon \& Manosevitch, 2010, p.89). By including touchscreen interactive tabletops digital participants interact with one another and the workshop material much as they would in physical virtual charrettes.

Aiming mainly 'to nurture local communities' (Gordon \& Manoseritch, 2010, p.205) Hub2 participants both' imagine and collectively experience their design' in virtual charrettes where ' particular attention is paid to the social and communal dimensions of the collaborative design processes' (Ibid, p.205). It too has been highly successful.

\section{Pathways for Wellbeing}

Of all the engagement techniques reviewed, Pathways to Wellbeing (Pathways) in which I have been involved in the early stages of testing, offers a unique avenue for ongoing, long-term engagement between citizens and local government. It has been developed to 'scale up participation' (McIntyre \& de Vries, 2011, p.155) and facilitate expanded decision making at the local level.

Essentially, it first aims to 'engage participation through participatory action research' (McIntyre-Mills, 2012, p.445) to enable service users, policy makers and providers to 'enhance awareness of our interconnectedness and our inclusion as part of nature ... and enable awareness of policy contradictions, rights, responsibilities and accountability for the next generation of life' (Ibid, p.445).

Scenarios are used as 'a starting point for an engaged conversation' (McIntyre \& de Vries, 2011, p.24) 'a discursive democracy that can help us change the way we live' (Ibid, p.24). It aims to help citizens use their own knowledge and experience to think through the future implications and consequences of their choices (Ibid, p.183). The choices relate to sustainable living and the extent to which people are prepared to adapt their lives to mitigate against the effects of climate change. Social, economic and environmental factors are all taken into account.

While enabling individual citizens to manage their pathways, the software enables analysis of the responses to inform and assist local government in matching service outcomes to the perceived needs of service users. It is conceived as an online process to work out where to 'draw the line' based on inclusive testing of ideas with those who are to be affected by the decisions (McIntyre-Mills \& de Vries, 2011, p.183).

Pathways also enables comparisons of where people choosing the three different pathways not only differ but overlap - and therefore find common ground in regard to their views - their concerns, values, priorities and approaches to how they want to live their lives. This facility is an excellent catalyst for shared conversations through multiple means, both online or off, adding to the richness of the planning while connecting people.

The Pathways project also will help in determining whether the technology itself can 'be useful to enable managing large, diverse data sets spanning many diverse interrelated variables about which residents have strong values' (McIntyre-Mills, 2012, p.447). Through a series of smaller pilots it is being gradually scaled up towards linking into social networking sites while expanding 'our horizon of solidarity through enabling people to develop a greater 
ability to think about the bigger picture' (Ibid, p.447).

Technology specialists identify five key criteria for engaging successfully online. Two could apply to any engagement - being that 'participation must be easy' (Cook, 2008, p.99) and 'contain personal value to the individual' (Ibid, p.99). In addition to easy access, the software must be intuitive, not requiring training - something that Pathways is striving towards.

The specialists also advise that online engagement works best when integrated with other processes and building on existing relationships (Cook, 2008, p.99). However, Pathways, virtual charrettes, QR codes and many other techniques have potential to reach unidentified participants for urban planning, thereby initiating the relationship.

As with offline engagement - as noted earlier - it must be 'built around the needs, goals, and concerns of the potentially engaged, not just the engagers' (Leinghninger, 2012b, p.4).However, research in the United States has found the amount of ICT in local governance to be dependent on community wealth, education and size, and can also emphasise the digital divide that in USA overlaps with marginalized immigrant and black neighbourhoods. While having potential to give minority groups equal access to local governance and decisionmaking processes (Cooper \& Balakrishnan, 2013, p.177-178) these limitations need to be addressed by combining face to face and on line engagement processes.

A survey of the use of e-tools by local government a few years ago found the main use of the Internet to be document-sharing, with less than 50 percent posting agendas of planning meetings and less than 30 percent using GIS and other maps statically or interactively to provide information. Less than 9 percent provided information in alternative languages, fewer used multimedia, only 3 percent provided tools for online discussion groups, and none at all used online tools for creating virtual meeting experiences (Cooper \& Balakrishnan, 2013, p.177). Since then the situation has changed across more progressive councils, notably Boston's Hub2 initiative and Spacing Toronto. Use for engaging communities in planning and break away from traditional planning processes is also increasingly being initiated by other stakeholders, including universities. Partnering with IBM early in 2013 the University of South Australia (UniSA) used a giant brainstorming collaboration - a jam - to discuss its new university strategy. Described by IBM's Graham Kittle as a 'more holistic conversation style' (Marton, 2013), the jam hosted seven different forums over 36 hours, involving thousands of voices in 18,500 threads of conversation. Apart from enabling so many voices to participate, the technology identified good ideas swiftly for further discussion.

\section{Citizen Science in Planning}

Technological advances also have enabled citizen science (public participation in scientific research - PPSR) to be applied to the planning field, expanding opportunities for eparticipation.

Traditionally focused on public collaboration to attain new science-based knowledge, its ability to crowdsource - being 'open calls for data or proposals for any inquiry or problem' (Cooper \& Balakrishnan, 2013, p.177) enables both planners and citizens to crowdsource from one another about plans, policies, detail on the condition of neighbourhoods and ideas for solving urban problems (Ibid, p.78).

At the same time, the wide range of activities and designs within citizen science has the ability to engage citizens through appealing to popular interest in games and hobbies while 
using the popular technology of 'smart phones, web-based data-entry forms, on-line geographic systems and online social networks' (Cooper \& Balakrishnan, 2013, p.179).

Various typologies of citizen science have been developed, each with different perspectives. Cooper and Balakrishnan cite Shirk et al's five models of the ways in which the public can participate in scientific research as framework for considering public participation in planning. There is a clear similarity to Arnstein's Ladder of Participation discussed earlier, and the IAP2 Public Participation Spectrum, discussed later in this paper.

Shirk et al's five models range from contractual projects - where contracted specialists conduct a specific investigation and generate a report, through to collegial contributions where 'non- credentialed individuals conduct research independently with varying degrees of expected recognition by institutionalized science and/or professionals' (Cooper \& Balakrishnan, 2013, p.180). Lying in between are: contributory projects - with some primary data is contributed by the public); collaborative projects - generally designed by scientists but citizens, while contributing data, also help in the refining design, analyzing data and disseminating information; and co-created projects - designed by scientists and the public together and involving some public participants in most/all aspects of the research (Ibid, p.180).

Cooper \& Balakrishnan observe that 'from a democratization perspective, PPSR styles represent the balance between the public and professionals in involvement, control and expression of their authority' (Cooper \& Balakrishnan, 2013, p.181).

A clear top-down to bottom-up process is clear in all three frameworks: Arnstein's Ladder of Participation, Shirk et al's five models of public participation in scientific research, and the IAP2 Public Participation Spectrum. Also clear is the view that the need for public participation is seen to increase proportionally to the scale of the project itself and its impacts on communities.

\section{Public Participation Findings and Recommendations}

These approaches all emphasise that we citizens 'are the dots and we are the interconnections. They are one. We make or break the connections' (McIntyre Mills \& de Vries, 2011, p.84). They also highlight the importance of using engagement processes that ensure stakeholders no longer have 'the luxury of maintaining their own narrow position' (Condon. 2008, p.13).

As McIntyre-Mills argues, diversity matters but 'only to the extent that diversity and freedom do not undermine the future of the next generation of life' (McIntyre-Mills \& de Vries, 2011, p.197). Instead, 'Systemic approaches [to] strive to honour the value of diversity and to continually address and redress the balance between individual and collective interests' (McIntyre-Mills, 2010) is needed. Evident too is that 'Designs need to address current, convergent social, economic and environmental challenges' (McIntyre-Mills \& de Vries, 2011, p.243). Design-led urban planning has largely failed to achieve this.

Charrettes are particularly good at bringing together stakeholders with different, often opposing viewpoints, to work, through mutual respect, as a team (Condon, 2008, p.13-14). Extending the charrette to include a virtual charrette enriches the discussion and the outcome.

However, too strong a focus on the physical form of design in charrettes runs the risk of 
further failure. It is cause for concern that the IDC, while recognizing that 'economic prosperity, the health of our planet, and wellbeing of our communities are not mutually exclusive agendas' (IDC, 2012, p.2) also stated that 'design-based methods offer a way of meeting each of these objectives' (Ibid, p.2). This is directly contrary to Cooper and Balakrishnan's view, noted earlier in this paper, that the emphasis by planning schools on physical design elements risks social elements, public opinions and local knowledge not being taken into account in planning (Cooper \& Balakrishnan, 2013, p.176). Former Adelaide Thinker in Residence, Laura Lee also emphasizes that design can only be successful in an integrated design process with 'an essentially human-centred focus' (Lee, 2010, p.10) aiming to 'improve the quality of life' (Ibid, p.10).

While face-to face relationships remain the most effective means of engaging individuals, online tools - such as Spaceshaper, Second Life (and other tools used in and adapted from citizen science), and Pathways to Wellbeing - can help 'involve people more meaningfully in the planning and publicizing of events and processes' (Leighninger, 2011b, p.5) for engaging. Therefore, 'the combination of face-to-face relationships and online connections can make a huge difference' (Ibid, p.5) to who is involved, and at what level.

Liebrucks concludes that social media's free-to-use social networking sites 'provide interactivity between communities and stakeholders - resulting in increased legitimacy and trust' (Liebrucks, 2010, p.6) and also that 'social media could be a vital tool in forming a mind shift to sustainable living' (Ibid, p.6).

\section{Principles for Public Participation}

Public participation case studies and work experience reveal that the levels of engagement may need to vary for different cases, at different stages of planning and development, or even for different stakeholders. The International Association for Public Participation (IAP2) has developed a useful participation spectrum (Appendix 1 - Resources for participation) with an increasing range of public influence - from informing through to empowering communities with decision-making and implementation (IAP2, 2006a, p.35, Twyford et al., 2006, p.133).

IAP2 based this continuum on engagement being 'Any process that involves the community in problem-solving or decision-making and uses community input to make better decisions' (as cited in Twyford et al., 2006, p.19). It takes into account context, parameters or prior decisions - such as South Australia's commitment to transit oriented development and compact urban form (Rann, 2012, p.19-20).

This paper supports Twyford in encouraging participation at the higher end of the spectrum to partner and empower, as engagement 'facilitates understanding, creates more sustainable decisions, and identifies critical issues early. It also acknowledges the human desire to have a say on those issues that affect us' (Twyford et al., 2006, p.13-14).

Twyford observes that three of the key challenges for any engagement process are: clarifying the problem; defining the decision-maker (together with the participants); and defining the objectives of the engagement process (Twyford et al., 2006, p.39). Addressing those challenges, with reference to the IAP2 Public Participation Spectrum and principles for engagement will help identify the appropriate methods of engagement.

Most South Australia government agencies have aspirational engagement principles, but their 
application tends to vary. Early in 2013 the State Government launched its Better Together: Principles of Engagement - a foundation for engagement in the South Australian Government, with the IAP2 Public Participation Spectrum as its basis to 'make better decisions by bringing the voices of communities and stakeholders into the issues that are relevant to them' (GOSA, 2013, p.7) and 'to be transparent about the level of engagement being used' (Ibid, p.9). Its principles seek to move the State Government 'from a culture of "announce and defend" to one of "debate and decide" (Ibid, p.4). They arguably do not go as far as the IAP2's Core Values in the promise that the public's contribution will influence the decision, but the State aims to develop its framework further from this initial foundation, through an ongoing series of workshops with employees from across all agencies.

The IAP2's set of seven Core Values for Public Participation (Appendix 1 - Resources for participation) provide a clear, concise, practical and flexible set of principles to use as is or as a base to develop or review principles for any area, including urban planning and development. Essentially, the core values recognize citizens' democratic right to have the opportunity to be involved in decision-making that affects them, to determine how they will be engaged, enabled to participate meaningfully and advised of the outcome of their participation.

\section{Conclusion towards achieving a holistic approach}

'Sustainable communities cannot be designed using the same methods that produced unsustainable ones' (Condon, 2008, p.123). This, and that we are caretakers or custodians for future generations (McIntyre-Mills \& de Vries, 2011, p.204, Australian Government, 2012, p.13) is becoming increasingly recognized by governments, planners and communities.

There is no one way in which to plan and design the urban landscape and no one way in which to engage. At the heart of both needs to be creativity - 'the necessary work of evolving community engagement practice using methods that honour people's individual and collective knowledge about their lives and their environments' (Sarkissian \& Hurford, 2010, p.4).

As McIntyre-Mills says 'It requires taking a leap into the unknown and using retroduced logic to make connections that enable us to see patterns (in the past and in the present) and to consider the implications for the future' (McIntyre-Mills \& de Vries, 2011, p.85). We must have the courage to do this.

Urban planning therefore needs to take a holistic approach 'taking into account the multiple layers and components of social systems' (Sarkissian et al., 2009, p.:218) and be long term focused. It is reliant on trust between the professional planners and community. Trust can only be built over 'a long period of sustained democratic policy implementation' (Chapman, 1996, p.191). However, the open dialogue of social media offers potential to increase trust, while citizen science in planning is expanding opportunities for e-participation.

At the same time 'democracy in its current form does not function effectively to enable us to address the convergent social economic and environmental challenges that we face' (McIntyre-Mills \& de Vries, 2011, p.222). 'We need both centralized controls to protect the global commons and decentralized engagement to test out our ideas' (Ibid, p.223).

An extension of the Aarhus Convention (applicable at present only to Europe) would 'enable freedom of information and the right of local people to participate in local governance' 
(McIntyre-Mills \& de Vries, 2011, p.281, Florini, 2003, p.87-88). While defining government as 'the decision-making apparatus of the state' (Fiorini, 2003, p.64) Fiorini notes the trend of declining national power (Ibid, p.66-75). Her work on new forms of democracy uphold the principle of subsidiarity - that decision needs to be taken at the lowest possible level (Singer, 2002).

Beyond that, McIntyre-Mills recommends development of 'a cycle including discursive democracy, deliberation on areas of concern based on structural dialogue and then voting on decisions' (McIntyre-Mills \& de Vries, 2011, p.243). The various approaches to public participation in urban planning explored here can contribute towards achieving that.

Engagement also needs to be guided by principles to determine both the process and the outcomes and to be 'as open and transparent as possible' (Cook, 2008, p.123).

Ultimately, unsatisfactory engagement of local people in urban development will result in 'loss of potential value for the scheme' (Chapman, 1996, p.191) in the short term, and in the long term 'alienation and dislocation' (Ibid, p.191) and the denial of future generations their right to quality of life.

\section{Resources for participation}

\section{- Australia's First Urban Design 'Protocol'}

(Australian Government, 2011b, p.11).

The Federal Government established Australia's first Urban Design 'Protocol', Creating Places for People - an urban design protocol for Australian cities, and launched it on 30 November 2011 at the fifth annual State of Australian Cities Conference.

It builds on earlier policy initiatives including the establishment of the Major Cities Unit, putting infrastructure planning reform onto the COAG agenda, requiring all state and territory governments to have strategic planning systems in place for their capital city by January 2012 (as a condition of further Federal infrastructure funding), and publishing a regular State of the Cities report to monitor performance of Australia's 18 largest cities.

Essentially, the Urban Design Protocol is founded on 5 pillars: productivity, sustainability, liveability, leadership and design excellence.Under Leadership and Governance, it has two key principles relevant to this essay - Engagement and Custodianship - each of which has several attributes to help achieve world-class urban design:Three key Engagement attributes are identified - to engage with relevant stakeholders - being: It acknowledges that urban design is primarily about creating places for people. It engages people in the development of their community.

It adopts a multi-disciplinary and collaborative approach to planning and design. Direct link to the Leadership \& Governance principles within the protocol http://www.urbandesign.gov.au/protocolframework/principles/index.aspx.The protocol relates directly to the National Urban Policy Our Cities, Our Future: a national urban policy for a productive sustainable and liveable future

- Liveability measures

(Australian Government, 2011c, p.141). Direct link: http://www.infrastructure.gov.au/infrastructure/mcu/soac.aspx

- Goals and Objectives of 'Our Cities. our Future' - a national urban policy for a productive, sustainable and liveable future 
(Australian Government, 2011d, p.16). Direct link: http://investment.infrastructure.gov.au/publications/administration/pdf/liveable_cities guidelines_version_1.1.pdf

- Arnstein's Ladder of Participation

(Cooper \& Balakrishnan, 2013, p.174)

\begin{tabular}{|c|c|c|c|}
\hline $\begin{array}{l}\text { Level of Citizen } \\
\text { Participation }\end{array}$ & $\begin{array}{l}\text { Arnstein's } \\
\text { Participation } \\
\text { Spectrum }\end{array}$ & $\begin{array}{l}\text { Planning } \\
\text { School }\end{array}$ & Planning Model \\
\hline Rung 8: Citizen Control & High Citizen Power & Pluralism & \multirow{3}{*}{$\begin{array}{ll}\text { - } & \text { Communicative } \\
\text { - } & \text { Bargaining } \\
\text { - } & \text { Marxist } \\
\text { - } & \text { Advocacy } \\
\text { - } & \text { Transactive }\end{array}$} \\
\hline Rung 7: Delegated Power & $\begin{array}{l}\text { Medium Citizen } \\
\text { Power }\end{array}$ & Pluralism & \\
\hline Rung 6: Partnership & Low Citizen Power & Pluralism & \\
\hline Rung 5: Placation & Tokenism & Synoptic & \multirow{3}{*}{$\begin{array}{ll}- & \text { Mixed Scanning } \\
- & \text { Incrementalism } \\
- & \text { Rational- } \\
& \text { Comprehensive } \\
- & \text { Synoptic } \\
\end{array}$} \\
\hline Rung 4: Consultation & Tokenism & Synoptic & \\
\hline Rung 3: Informing & Tokenism & Synoptic & \\
\hline Rung 2: Therapy & Non-participation & $\begin{array}{l}\text { "Blueprint" } \\
\text { Planning }\end{array}$ & \multirow[t]{2}{*}{ - $\quad$ Blueprint Planning } \\
\hline Rung 1: Manipulation & Non-participation & $\begin{array}{l}\text { "Blueprint" } \\
\text { Planning }\end{array}$ & \\
\hline
\end{tabular}

IAP2 Core Values for Public Participation (IAP2a, 2006, p.25-28, Twyford et al., 2006, p.92)

1. The public should have a say in decisions about actions that affect their lives.

2. Public participation includes the promise that the public's contribution will influence the decision.

3. Public participation promotes sustainable decisions by recognizing and communicating the needs and interests of all participants, including decision-makers.

4. Public participation seeks out and facilitates the participation of those potentially affected.

5. Public participation seeks input from participants in designing how they participate.

6. Public participation provides participants with the information they need to participate in a meaningful way.

7. Public participation communicates to participants how their input affected the decision.

IAP2's Public Participation Spectrum (IAP2a, 2006, p.35) 


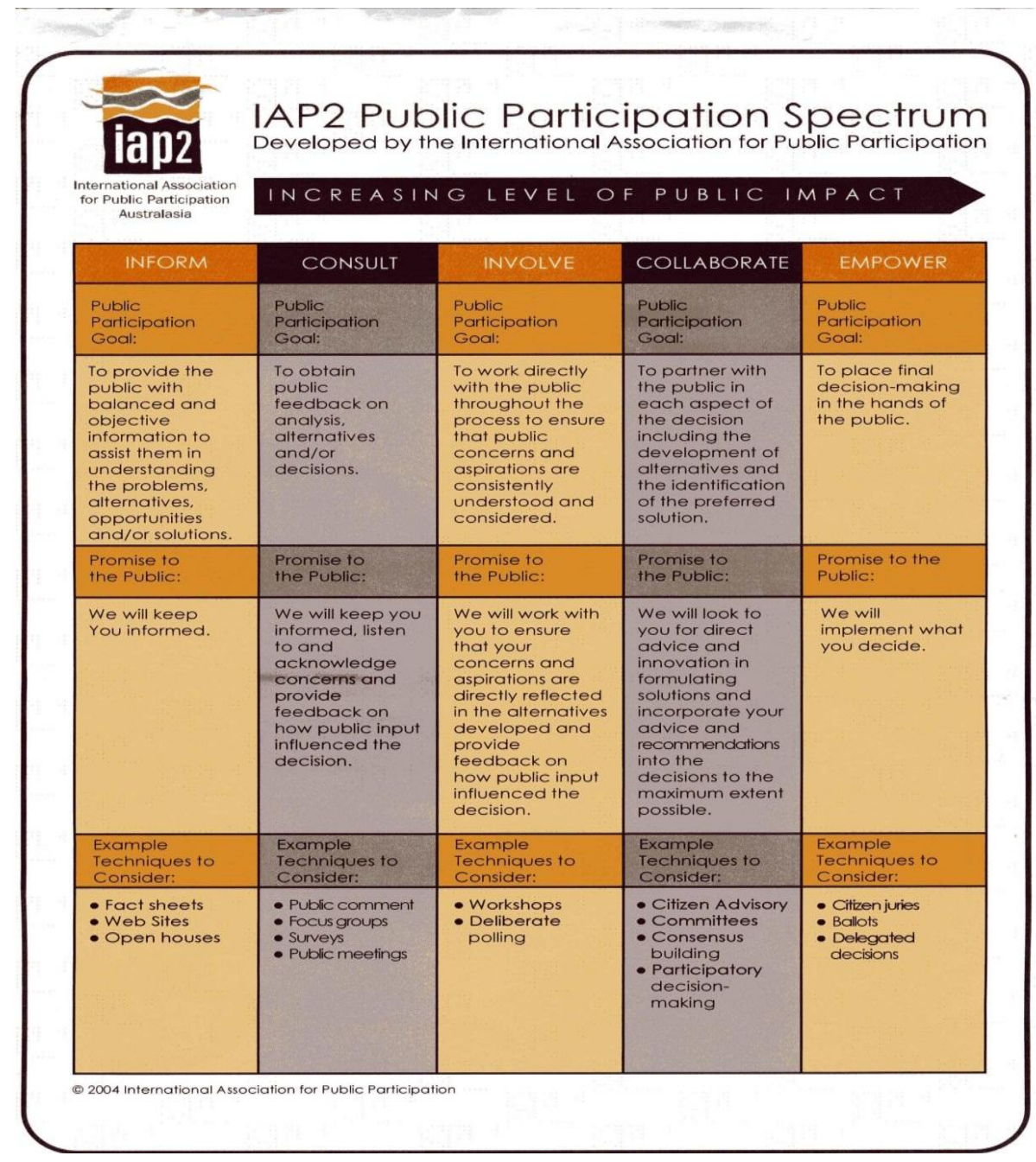

\section{References}

Australian Government. 2011a. Our cities Our Future: A national urban policy for a productive, sustainable and liveable future. Canberra: Department of Infrastructure and Transport, Australian Government.

http://www.infrastructure.gov.au/infrastructure/mcu/files/Our_Cities_National_Urban_Policy Paper_2011pdf.

Australian Government. 2011b. Creating Places for People - an Urban Design Protocol for Australian Cities. Major Cities Unit of the Department of Infrastructure and Transport, Canberra: Australian Government. http://www.urbandesign.gov.au/

Australian Government, 2011c. State of Australian Cities 2011. Report by the Major Cities Unit of the Department of Infrastructure and Transport, Canberra: Australian Government. http://www.infrastructure.gov.au/infrastructure/mcu/soac.aspx

Australian Government. 2011d. Liveable Cities Program, Nation Building Infrastructure Investment Program Guidelines, Department of Infrastructure and Transport Audit Report 2013/14. Canberra: Australian Government. http://investment.infrastructure.gov.au/publications/administration/pdf/liveable_cities guidelines_version_1.1.pdf 
Australian Government. (2009, 7 December). Capital City Strategic Planning Systems, Council of Australian Governments' Meeting (COAG) Communique, pp8. Canberra: Australian Government. http://www.coag.gov.au/sites/default/files/2009-12-07.pdf

Beck, U. 2007. World at Risk, Cambridge: Polity Press.

Boulton, S., Cis, D., Mendonca, L., Pohl, H., Remes, J., Ritchie, H. , \& Woetzel, J. 2013. How to make a city great, McKinsey Cities Special Initiative report. McKinsey \& Company.

Castells, M. 1996. The Information Age: Economy, Society and Culture. Vol. 1: The Rise of the Network Society. Oxford: Blackwell Publishers.

Chapman. D (ed). 1996. Creating Neighbourhoods and Places in the Built Environment. London: E. \& F.N. Spon.

Condon, P. M. 2008. Design Charrettes for Sustainable Communities. Washington: Island Press.

Cook, A. 2012. Developing Visual Research tools to 'do planning' with Children. Workshop paper for the Place leaders Association (PLA) Champions' Forum, 2-3 August, 2012. Adelaide.

Cook, N. 2008. Enterprise 2.0 - How Social Software Will Change the Future of the World. Farnham: Gower Publishing.

Cooper, C. And Balakrishnan, A. 2013, Citizen Science Perspectives on E-Participation in Urban Planning, In Nunes Silva, C. (Ed.) Citizen E-Participation in Urban Governance: Crowdsourcing and Collaborative Creativity. Lisbon: University of Lisbon, USA: IGI Global.

Florini, A. 2003. The Coming Democracy: New Rules for Running a New World. Washington DC: Island Press.

Gillin, P. 2009. Secrets of Social Media Marketing. Fresno, California: Quill Driver Books.

Gleeson, B. 2013. Unsustainable cities a product of growth fetish. Opinion:Brendan Gleeson/The Conversation www.theconversation.edu.au In Daily. 13 May 2013.

http://indaily.com.au/news/2014/05/13/unsustainable-cities-a-product-of-growth-fetish/

Gordon, E. \& Koo. G. 2008. Placeworlds: Using Virtual Worlds to Foster Civic Engagement. Space and Culture. Vol. 11. No. 3.

Gordon, E. \& Manosevitch, E. 2010. Augmented deliberation: Merging physical and virtual interaction to engage communities in urban planning. New Media \& Society. Vol. 13. No. 1. pp.75-pp.95.

Government of South Australia (GOSA), 2013. Better Together: Principles of Engagement. Department of Premier \& Cabinet, Government of South Australia, Adelaide.

Gunter, J. 2013. Harnessing the Power of an Open Design Community http://www.openideo.com/open/e-waste/realisation/harnessing-the-power-of-an-opendesign-community/ 31 January 2013.

Habermas, J. 2001. The Postnational Constellation, Chpt. 4. pp58-pp112. Cambridge. Mass: MIT Press.

Held, D. 2004. Globalisation: the Dangers and the Answers. Polity Press.

Hewett, B. 2012. In Integrated Design Strategy for inner Adelaide - Placeshaping Framework. Integrated Design Commission. Adelaide: Government of South Australia.

Hoggett, P. 2009. Politics, Identity and Emotion. Boulder. Col. USA: Paradigm Publishers.

Hoy, M Community engagement: keep one foot in cyberspace and one in the real world.

Guardian Professional Local Government Network, posted 14 May 2013.

Hurley, T. 2010. Place Making for People: Case studies in delivering community expectations. Sydney: Place Leaders Association Limited. 
Integrated Design Commission (IDC). 2012. An Integrated Design Strategy for inner Adelaide - Placeshaping Framework. Adelaide: Government of South Australia.

International Association for Public Participation (IAP2). 2006a. Planning for Effective Public Participation. Student training manual for IAP2 Certificate Program in Public Participation. Denver. Colo: IAP2.

International Association for Public Participation (IAP2). 2006b. Techniques for Effective Public Participation. Student training manual for IAP2 Certificate Program in Public Participation. Denver. Colo: IAP2.

Johnston, S. 2012. The Adelaide Review. August 2012. Issue 390. pp27.

Lee, L. 2010. Integrated Design: Design as an Agent of Change. Place Magazine. June 2010 issue. pp. 10. Australian Institute of Architects (SA Chapter). Adelaide

Liebrucks, C. 2010. Exploring Feasibility of a Virtual Charrette in South Australia. Adelaide: Property Council of Australia \& University of Adelaide.

Leighninger, M. 2011a. Designing the next form of democracy. Article on Deliberative Democracy Consortium Forum. Posted 7 December 2011.

http://www.businessofgovernment.org/sites/default/files/A\%20Managers\%20Guide\%20to\%2 0Evaluating\%20Citizen\%20Participation.pdf

Leighninger, M. 2011b. Using Online Tools to Engage - and be Engaged by - The Public. Using Technology Series Report. Deliberative Democracy Consortium Forum. http://www.businessofgovernment.org/sites/default/files/Using\%200nline\%20Tools\% 20to\%20Engage\%20The\%20Public_0.pdf

Mannix, L. 2014. Planning policies upset "vested interests":Rau. Indaily 13 March 2014. http://indaily.com.au/news/2014/03/13/planning-policies-upset-vested-interests-rau/

Marsh, S, 2013, Guardian Professional Local Government Network, http://www.guardian.co.uk/local-government-network/2013/jun/05/workshopengaging-residents-online?goback=\%2Egde 4239277 member_247676619 posted 6 June 2013.

Marton, L. 2013, How UniSA used co-creation to engage stakeholders in the strategic planning process. Marketingmag.com. http://www.marketingmag.com.au/interviews/how-unisa-used-co-creation-to-engagestakeholders-in-the-strategic-planning-process-46655/\#! Posted 29 November 2013.

McIntyre-Mills, J. and De Vries, D. Transformation from Wall Street to Well-being, 2013. Systems Research and Behavioural Science, Vol. 30. No. 4, July-August 2013, pp444pp469.

McIntyre-Mills, J. and De Vries, D. 2009. How Lemmings on Wheels can Make a U-Turn Through Social Inclusion and Democracy, Systemic Practice and Action Research, Vol. 22. No. 3, pp173-200.

McIntyre-Mills, J. with De Vries, D. 2011, Identity, democracy and Sustainability. Litchfield Park. USA: Emergent Publications..

McIntyre-Mills, J. 2014. The challenges for social and environmental justice in an Increasingly vulnerable and unequal world. Paper presented at the International Sociology Association (ISA) XVIII World Congress of Sociology, Japan. July 2014.

McIntyre-Mills, J. 2010, Towards a cosmopolitan approach for social and environmental justice, New Community Quarterly, Vol. 8. No. 3. pp. 4-13.

McIntyre-Mills, J. 2006. Systemic Governance and Accountability. London, New York: Springer.

McIntyre-Mills, J. 2003. Critical Systemic Praxis for Social and Environmental Justice. New York: Kluwer Academic / Plenum Publishers.

McIntyre-Mills. J. 2000. Global Citizenship and Social Movements - Creating Transcultural Webs of Meaning for the New Millenium. Harwood Academic Publishers. 
O'Leary, K. 2011. Instead of an overarching vision for Adelaide, Rann's administration opted for a string of showcase developments, Adelaide Advertiser, pp18.

Rann, M. 2012. Revitalising cities. Lecture given at University of Auckland, 16 August, 2012. Visiting Senior Research Fellow in Political Studies.

Read, S. Rosemann, J. \& van Eldijk, J. 2005. Future City. Spon Press. New York.

Rogers, N. 2012. Building Communities. Background Paper. Department for Communities and Social Inclusion. Adelaide: Government of South Australia.

Sarkissian, W. \& Hurford, D. 2010. Creative Community Planning - Transformative Engagement Methods for Working at the Edge, London: Earthscan.

Sarkissian. W. Hofer, N. Shore, Y. Vajda, S. \& Wilkinson, C. 2009. Kitchen Table Sustainability - Practical Recipes for Community Engagement with Sustainability, London: Earthscan.

Sarkissian, W. \& Cooper Marcus, C. 1986. Housing as if People Mattered. Berkley: University of California Press.

Singer, P. 2002. One World: The Ethics of Globalisation. Melbourne: The Text Publishers.

Stein, D. 1993. Winning Community Support for Land Use Projects. Washington DC: The Urban Land Institute.

Stoker, G. 2000. Pierre, J. (Ed) 2000. Urban Political Science and the Challenge of Urban Governance. Chapt. 5. Pp91-109. In Pierre. J. (Ed) 2000. Debating Governance. Oxford: Oxford University Press.

The Australian Centre for Social Innovation (TACSI). 2014. Verdicts on the Jury. Adelaide: New Democracy Foundation. http://yoursay.sa.gov.au/media/W1siZiIsIjIwMTQvMDgvMjIvMDFfNDVfNTZfMzk xX1ZlcmRpY3RzX29uX3RoZV9KdXJ5X1RBQ1NJLnBkZiJdXQ/Verdicts\%20on\% 20the\%20Jury_TACSI.pdf

Toohey, P. 2012. The dying city: Detroit has gone from prosperity to poverty - but some still hope. Adelaide Sunday Mail. 15 July 2012. pp29.

Twyford, V., Waters, S., Hardy, M., \& Dengate, J. 2006. Beyond Public Meetings: Connecting Community Engagement with Decision-Making. Sydney: Vivien Twyford Communications Pty. Ltd.

Weatherill, J. 2012a. About Renewal SA, Premier's statement on launching the Urban Renewal Authority, March 2012. Renewal SA website http://www.renewalsa.sa.gov.au/AboutRenewalSA.aspx accessed 10 May 2013

Weatherill, J. 2012b. Premier's Keynote Address, the Australian Institute of Urban Studies Seminar 24 February 2012. Adelaide.

Williams, T. 2013. Competing for vision splendid, The Advertiser, 8 June 2013. pp66. 